\title{
Orthokeratinized odontogenic cyst associated with multinucleated giant cell reaction: report of unusual findings
}

\author{
Cisto odontogênico ortoceratinizado associado à reação de células gigantes multinucleadas: relato de achados \\ incomuns
}

\author{
Lívia Natália Sales BRITO' \\ Francisco Jadson LIMA² \\ Pollianna Muniz ALVES 1 \\ Cassiano Francisco Weege NONAKA ${ }^{1}$ \\ Gustavo Pina GODOY3
}

\begin{abstract}
Orthokeratinized odontogenic cysts are developmental odontogenic cysts, presenting with low frequency, low rate of recurrence and their ethiopathogenesis is unknown. Radiographically, they show a radiolucent area in the mandibular posterior region. The aim of this report is to describe an unusua/ case of orthokeratinized odontogenic cysts, radiographically exhibiting radiopaque areas with an aspect of calcifications in the lesion. Based on this, the clinical hypothesis of ameloblastic fibro-odontoma was suggested. After incisional biopsy and microscopic analysis, the conclusive diagnosis was orthokeratinized odontogenic cysts. The radiopaque foci were observed to be associated with a foreign body reaction. The patient was submitted to surgery under local anesthesia, with intraoral access for complete excision of the lesion and to re-establish esthetics. After follow-up of 24 months there were no signs of recurrence. Knowledge of this type of reaction is important because of the risk that the lesion may mimic a potentially more aggressive lesion, affecting the choice of treatment.
\end{abstract}

Indexing terms: Giant cells. Odontogenic cysts. Pathology.

\section{RESUMO}

Os cistos odontogênicos ortoceratinizados são cistos de desenvolvimento de origem odontogênica, de baixa frequência, etiopatogenia desconhecida e baixa taxa de recorrência. Radiograficamente, apresenta-se como uma área radiolúcida em região posterior de mandíbula. O objetivo deste artigo é descrever um caso não usual de cistos odontogênicos ortoceratinizados, que exibia, radiograficamente, focos radiopacos semelhantes à calcificações, no interior da lesão, sugerindo diagnóstico clínico de fibro-odontoma ameloblástico. Após a biópsia incisional e análise microscópica, o diagnóstico conclusivo foi de cistos odontogênicos ortoceratinizados. Observou-se que os focos radiopacos estavam associados, microscopicamente, a presença de uma reação de células gigantes multinucleadas por corpo estranho. O paciente foi tratado cirurgicamente, sob anestesia local, com acesso intrabucal para remoção total da lesão, com o restabelecimento da estética e sem sinais de recidiva após 24 meses. A importância do conhecimento deste tipo de reação dar-se pelo risco de mimetizar uma lesão potencialmente mais agressiva, direcionando a escolha do tratamento da lesão.

Termos de indexação: Células gigantes. Cistos odontogênicos. Patologia.

\section{INTRODUCTION}

The orthokerainized odontogenic cyst (OOC) was - for a long time - considered a less aggressive counterpart of the Keratocystic odontogenic tumor (KOT). However, as it presented less aggressive clinical, histopathological and behavioral characteristics ${ }^{1-2}$, according to the World Health Organization (WHO) in 2005, it was reclassified as a distinct clinical entityz-3.

The OOC is relatively rare, accounting for only $0.4 \%$ of cystic lesions of odontogenic origin ${ }^{4}$. Observed predominantly in adult Caucasians of the male sex, its peak incidence is found between the third and fourth decades of life ${ }^{2,4}$. This cyst generally presents as a single, asymptomatic, radiolucent lesion, localized predominantly in the posterior region of the mandible e-3,5. $^{2-3}$.

The histopathological characteristics it presents are an epithelium with an orthokeratinized lining, made up of a prominent granulous layer, and basal layer of flattened cuboidal cells that show no trend towards the palisaded nuclear arrangement ${ }^{1-2,6-7}$. Their treatment consists of marsupialization or surgical enucleation ${ }^{2,7}$. These lesions show a low level of aggressiveness and tendency towards recurrence at a rate lower than $4 \%$ 2,8.

From this aspect, the purpose of the present article was to report a case of $\mathrm{OOC}$ with radiographic aspects not

\footnotetext{
${ }^{1}$ Universidade Estadual da Paraíba, Departamento de Odontologia, Programa de Pós-Graduação em Odontologia. Rua Baraúnas, 351 , Bairro Universitário, 58429-500, Campina Grande, PB, Brasil. Correspondência para / Correspondence to: PM ALVES. E-mail: <pmunizalves@gmail.com>.

${ }^{2}$ Universidade Federal do Rio Grande do Norte, Programa de Pós-graduação em Patologia Oral. Natal, RN, Brasil.

${ }^{3}$ Universidade Federal de Pernambuco, Departamento de Patologia. Recife, PE, Brasil.
} 
usually reported in the literature, emphasizing the importance of distinguishing this lesion from other more aggressive types.

\section{CASE REPORT}

The patient, a 25-year-old man sought a private dental service with the intention of undergoing orthodontic correction. After accurate anamnesis and extraoral physical exam with the patterns of normality, the intraoral clinical exam was performed. During this exam, the presence of a tumefaction was found in the posterior region of the mandible on the left. This was asymptomatic and of a firm consistency on palpation. In the panoramic radiographic exam of the maxillae, a radiolucent, unilocular area was observed in the region of the mandibular body. This had an expansive aspect, covering the region from tooth 34 to tooth 38 , with root resorption of the teeth involved. Inside the lesion the presence of radiopaque areas were evident and outstanding, compatible with calcified material deposition (Figure 1). Based on these findings, clinical diagnoses of cystic lesion of odontogenic origin, or odontogenic tumor of epithelial origin such as ameloblastic fibro-odontoma and calcifying epithelial odontogenic tumor were suggested. Therefore, incisional biopsy was performed, and the material removed was sent for histopathological analysis.

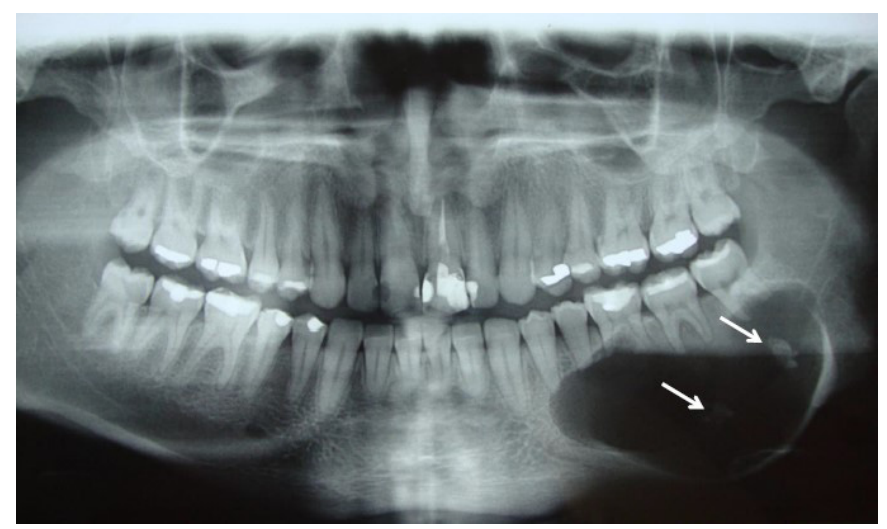

Figure 1. Panoramic radiographic image of the maxillae, showing an extensive, uniloc ular radiolucent area, with areas of radiopaque foci (arrows), in the region of the mandibular body, covering the region from tooth 34 to tooth 38

On microscopic examination, a fragment of cystic lesion was observed, lined with hyperorthokeratinized, stratified, pavimentous epithelium, exhibiting a corrugated surface, an evident granulous layer and a flat epitheliumconnective interface (figure 2A). The cystic capsule was shown to be composed of dense fibrous connective tissue, exhibiting slight chronic inflammatory infiltrate and moderate vascularization (figure 2B). An uncommon finding observed in the capsule as well, was the presence of basophilic areas compatible with calcified material deposition, surrounded by a multinucleated giant cell reaction (figures 2C 2D).

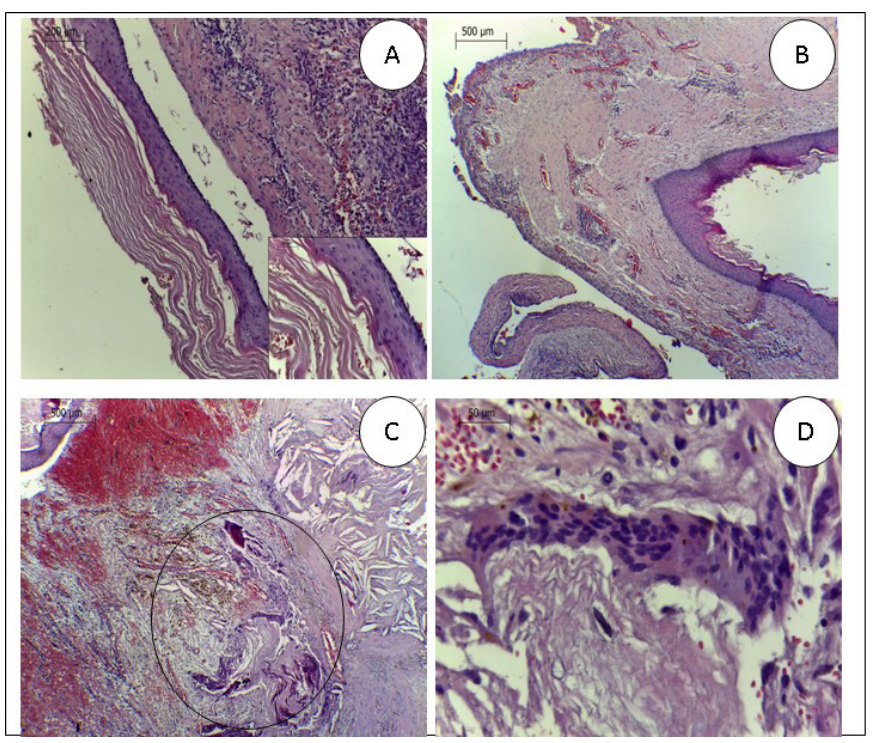

Figure 2. A) Note the cystic lesion fragment, lined with hyperorthokeratinized stratified pavimentous epithelium with a corrugated surface and flat epitheliumconnective interface. (HE 100X). There was outstanding evidence of a thick layer of orthokeratin (HE 400x). B) Photomicrograph exhibiting the cystic capsule with slight chronic inflammatory infiltrate and moderate vascularization. (HE - 40X). C) Note the multinucleated giant cell reaction around the basophilic areas that were compatible with calcified material deposition (circle) (HE, 40X). D) At higher magnification, the multinucleated giant cells could be observed (HE, 400X)

Therefore, in view of the histopathological characteristics observed, the lesion was diagnosed as an OOC. Complete surgical removal of the lesion was performed, and the patient was followed-up for 24 months, free of symptomatology and without signs of recurrence of the lesion. However, after this period, we lost touch with the patient because he moved to a different place.

\section{DISCUSSION}

The $\mathrm{OOC}$ is a relatively uncommon developmental cyst of an unknown etiology ${ }^{1-2}$. However, the etiopathogenesis of OOCs is believed to be associated with a mutation of the Patched gene $(\mathrm{PTCH})^{1,5}$. OOCs comprise $10.5 \%$ of the cysts previously classified as KOTs ${ }^{2}$. Nevertheless, distinction must be made between these two 
entities, because KOTs exhibit a locally aggressive behavior and are predisposed to recurrence ${ }^{1-2,5,9}$, and have also been found to be associated with the basal cell nevoid carcinoma syndrome, which is not observed in OOCs ${ }^{1-2,5,9}$.

With the purpose of comparing the proliferative activity of OOCs and dos KOTs, Dong et al. 1 evaluated the immunohistochemical expression of $\mathrm{Ki}-67$ and p63 in the epithelial lining of these lesions, and observed that in OOCs there was lower immunoexpression of both Ki67 and p63, thus inferring that OOCs were shown to be less aggressive than KOTs due to their lower level of proliferative activity.

These cysts generally present as single asymptomatic lesions ${ }^{10}$, in the posterior mandibular region ${ }^{2,7-8}$. Nevertheless, some reports have shown painful symptomatology associated with secondary infection ${ }^{7-8}$, and extension between 1 and 3 centimeters. However, cases of large dimensions have been reported ${ }^{5,7}$, as in the case here reported, the size of which at the largest diameters was 10.3 centimeters, covering the region from the premolars up to the body of the mandible.

Radiographically, OOCs present as well-delimited, and predominantly unilocular radiolucent lesions ${ }^{2,5,8}$ that may be associated with the crown of an impacted tooth. It is frequently confused with the dentigerous cyst or with $\mathrm{KOT}^{2,8}$. The case reported here differed from those in the reports found in the literature, relative to its extensive size and expansive radiolucent aspect, with the presence of radiopaque regions within it, and with the aspect of possible rupture of the cortical bone, which could make a differential diagnosis with the calcifying epithelial odontogenic tumor and ameloblastic fibroma-odontoma ${ }^{11}$. Furthermore, the teeth involved showed areas of apical root resorption, a fact that justified the hypotheses of ameloblastic fibromaodontoma or calcifying epithelial odontogenic tumor. However, due to the radiographic similarities to these lesions, it is important to emphasize that the conclusive diagnosis must be based on careful clinical, radiographic exams and the histopathological findings ${ }^{4-5}$.

As histopathological characteristics, the OOC presents an epithelium with a uniform, orthokeratinized lining, made up of a prominent granulous layer and a basal layer of flattened cuboidal cells ${ }^{1-3,5-6}$ - aspects similar to those that were found in the case here reported. However, inside the cystic capsule, the presence of multinucleated giant cells was observed; these are considered an uncommon histopathological finding in this type of lesion.

Multinucleated giant cells arise as a result of the fusion of macrophages, represent a terminal state of differentiation, and play an important role in the chronic inflammatory response $\mathrm{e}^{12}$. Foreign body multinucleated giant cells arise from an inflammatory response resulting from the persistent presence of a non-phagocytable material ${ }^{13}$.

In spite of being rare, developmental cysts may present infections, as in the case reported by Carvalho et al. ${ }^{7}$, in which the secondary infection was associated with an $\mathrm{OOC}$, where rupture of the cortical bone served as the port of entry for the infection. In the case here reported, the radiographic images could suggest that rupture of the cortical bone could also have served as port of entry of the infection that generated an inflammatory response as a reaction to a foreign body. When reporting an uncommon case of root cyst with a mixed radiographic aspect, RamosPerez et al. ${ }^{3}$ considered one of the possibilities to be an extravasation of filling material into the periapical region, thus causing an inflammatory reaction that triggered tissue necrosis and consequent formation of large dystrophic calcifications. This would justify the mixed radiographic aspect of the case.

There is no completely established therapeutic strategy for treating the $\mathrm{OOC}^{5}$. Enucleation with or without curettage and marsupialization followed by enucleation are the most recommended surgical interventions, however, a trend has been observed towards performing peripheral osteotomy in cases of multilocular and relatively extensive lesions. Due to the large extension of the lesion in the case here reported, the option was to perform surgical enucleation of the lesion, and placement of a surgical duct for local drainage, because the inflammatory content could maintain hydrostatic pressure on the injured tissue, and sometimes compromise the surgical repair. Therefore, the duct was maintained for seven days, and after its removal, the patient's rapid recovery was observed.

\section{CONCLUSION}

OOCs represent a rare group of developmental odontogenic cysts that cannot be classified as the other established types, therefore constituting a distinct clinical entity. They are predominantly radiolucent lesions, however, the presence of radiopaque areas within them may be associated with a multnucleated giant cell reaction. Because this was not an aspect commonly observed, it was important to have knowledge of this type of reaction, due to the risk of it mimicking a potentially more aggressive lesion; and this directed treatment of the patient. 


\section{Collaborators}

FJ LIMA was responsible for supplying the data for the research. PM ALVES, CFW NONAKA, GP GODOY and FJ LIMA analysed the data and designed the research. LNS BRITO wrote the manuscript.

osteoclasts and dendritic cells. Exp Mol Pathol. 2011;91(3):67381 doi: 10.1016/j.yexmp.2011.06.012

9. De Souza LB, Gordón-Nuñez MA, Nonaka CFW, De Medeiros MC, Torres TF, Emiliano GB. Odontogenic cysts: demographic profile in a Brazilian population over a 38-year period. Med Oral Patol Oral Cir Bucal. 2010;15(4):583-90. doi: 10.4317/ medoral.15.e583

2. MacDonald DS, Li TK. Orthokeratinized odontogenic cyst in a Hong Kong community: the clinical and radiological features. Dentomaxillofac Radiol. 2010;39(4):240-5. doi: 10.1259/ $\mathrm{dmfr} / 36547074$

3. Ramos-Perez FM, Pontual AA, França TR, Pontual ML, Beltrão RV, Perez DE. Mixed periapical lesion: an atypical radicular cyst with extensive calcifications. Braz Dent J. 2014 Oct; 25(5):44750. doi: 10.1590/0103-6440201300235

4. Diniz MG, Galvão CF, Macedo PS, Gomes CC, Gomez RS. Evidence of loss of heterozygosity of the PTCH gene in orthokeratinized odontogenic cyst. J Oral Pathol Med. 2011;40(3):277-80. doi: 10.1111/j.1600-0714.2010.00977

5. Vignery A. Macrophage fusion: the making of osteoclasts and giant cells. J Exp Med. 2005;202(3):337-40. doi: 10.1084/ jem.20051123

6. Boffano P, Gallésio C. Peculiar case of orthokeratinised odontogenic cyst: a peripheral counterpart of the intraosseous entity?. Br J Oral Maxillofac Surg. 2012;50(5):75-77. doi: 10.1016/j.bjoms.2011.09.019

7. Carvalho $\mathrm{CH}$, Aquino AR, Nonaka CFW, Pereira SJS, Germano Rocha GA, Pereira PL. Infected orthokeratinized odontogenic cyst: a rare cause of facial cellulitis. Braz Dent J. 2012;23(5):6126. doi: 10.1590/S0103-64402012000500025

8. McNally AK, Anderson JM. Foreign body-type multinucleated giant cells induced by interleukin-4 express select lymphocyte co-stimulatory molecules and are phenotypically distinct from
Received on: 11/3/2017

Final version resubmitted on: 6/7/2017

Approved on: 30/8/2017 